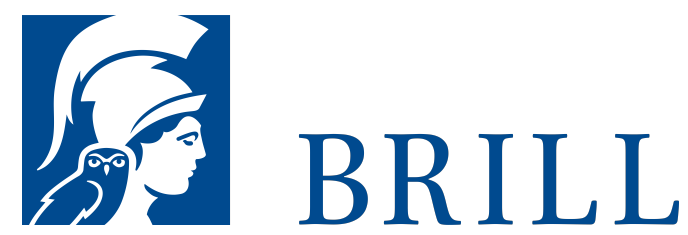

\title{
Marie-Alain Couturier. Ein Traditionalist und Revolutionär
}

Eine theologische Biografie

Author: Hartwig Bischof

'Alles Ewige ist gleichzeitig modern', schrieb Couturier vor über fünfzig Jahren. Heute ist er in seiner Bedeutung kaum zu überschätzen, damals leitete er mit dieser Aussage die Notwendigkeit zu einem umfassenden Dialog zwischen zeitgenössischer Kunst und der Theologie ab. So wurden Matisse, Picasso, Braque, Léger, Le Corbusier und einige andere große Gestalten aus der Kunst des 20. Jahrhunderts zu seinen herausragenden Gesprächspartnern. Diese Dialoge führten durch die von ihm geleitete Zeitschrift 'L'Art Sacré' nicht nur zu einer außergewöhnlichen Breitenwirkung, sondern bescherte der Kunstgeschichte auch einige herausragende sakrale Bauten wie in Ronchamp, Assy, Audincourt, Vence und L'Arbesle. Die vorliegende Arbeit bietet eine Aufarbeitung von Leben, Werk und Wirken von Marie-Alain Couturier, einige Glanzlichter aus der Zeitschrift 'L'Art Sacré' werden präsentiert, die wichtigen Bauwerke vorgestellt und die theologischen Voraussetzungen und Auswirkungen ausführlich besprochen.

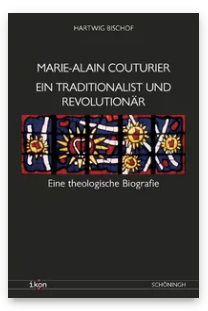

Pages: 304

Seiten

Language:

German

Subjects:

General,

Theology and

World

Christianity

Publisher: Brill |

Schöningh

Series:

IKON. Bild +

Theologie

Paperback

Publication date:

$25 \mathrm{Jul} 2007$

ISBN: 978-3-

506-76327-3

List price

USD \$40.00 
For more information see brill.com

Order information: Order online at brill.com +44330 333 0049 | customerservices@brill.com Submission information: brill.com/authors

Titles published by Brill | Fink, Brill | mentis or Brill | Schöningh: +49(o)715413279216| brill@brocom.de 